\title{
Quality Education in Second Cycle Institutions: The Role of the Private Sector
}

\author{
BABA BLONCH ADOMBILLA $^{1} \quad$ AKUBAH JOSEF KRIS $^{2}$ AZEESI ROGER ${ }^{3}$ \\ 1.BABA BLONCH ADOMBILLA, Bolgatanga Polytechnic, Department of Secretaryship and Management \\ Studies, Box 767, Bolgatanga, Ghana \\ 2.AZEESI ROGER, Bolgatanga Polytechnic, Department of Secretaryship and Management Studies, Box 767, \\ Bolgatanga, Ghana \\ 3.AKUBAH JOSEF KRIS , Great Victory International Academy, Bolgatanga, Ghana
}

\begin{abstract}
The study was an assessment of quality education; the role of the private sector. Questionnaire and interview schedules were used to collect data from 175 respondents in second cycle institutions. SPSS and Microsoft Excel were used to analyze the data. The study discovered varied determinants of quality education for private second cycle institutions; critical of which are well-motivated teachers, availability of instructional materials, effective monitoring and supervision and recognition of individual differences. Private institutions could contribute enormously to quality education through strong partnership between the public and private educational sector. The private second cycle schools are constraint with inadequate infrastructure, inadequate professional teachers, untimely payment of school fees, excessive expectation of parents towards students' performance and minor interference by parents administratively. Quality education should be tackled comprehensively and incrementally. The study recommends an urgent need for public-private sector partnership for quality education. Private schools should be granted access to the GET fund; and there should be a strong monitoring and evaluation team for quality education from the Ghana Education Service. The study also recommends that, Ministry of Education should chatter a principle, comprehensive and incremental approach to deal with quality education issues in the second cycle education. Finally, the study recommends collaboration between Ghana Education Service and Ghana Youth Employment and Entrepreneurial Agency (YEA) for regular supply of non-professional graduate teachers to the second cycle institutions.
\end{abstract}

DOI: $10.7176 / \mathrm{JEP} / 10-9-17$

Publication date:March $31^{\text {st }} 2019$

\section{Background}

Quality Education plays a vital role in the total development of any given community. Governments, since the attainment of our political independence in 1957, have made concerted efforts to drive educational policies across the length and breadth of the country. In Ghana, second-cycle education is recognized as critical to the country's quest to develop at a faster rate because, it is the most accessible form of higher education today with greater potential of sustaining higher levels of literacy, increasing political awareness, strengthening democracy and producing a pool of middle-level manpower crucial to national development (Quist, 2003).

Private participation in the provision of formal education in Ghana dates back to the castle schools days. At that time, schools were privately set up in the homes of the white merchants and missionaries and used as centers for providing literacy skill training to their African wives as well as to turn many black youth into clerks and catechists. Currently, the private sector has become the engine of growth for many national economies. Primarily, education is to equip the student with the necessary skills and knowledge taking into consideration the individual's interests.

The Oxford dictionary (2014), defines Education as the process of receiving or giving systematic instruction, especially at a school or university. Again, it defines Quality as the standard of something as measured against other things of similar kind; the degree of excellence of something. Education therefore must be given a certain level of measure to satisfy the recipient and the giver. Cronkite (1993), an iconic American broadcast journalist once said, "Whatever the cost of our libraries, the price is cheap compared to that of an ignorant nation". So, to develop a society, the first thing every good government does is to solve problems of education. This is why the 1992 Republican Constitution of Ghana states in article 21, clause 9 that, everyone has an inalienable right to education, which shall be progressively free. Thus, every Ghanaian young and old, is entitled to be educated.

Several international organizations have made several statements on quality and affordable education. The Dakar Framework for Action in the year 2000 declared that, access to Quality Education was the right of every child (Education for All Global Monitoring Report, 2005). Also, in the 1994 Salamanca conference in Spain by UNESCO (Salamanca Statement and Framework for Action on Special Needs Education, 1994), it was noted that: "Every child has a fundamental right to education and must be given the opportunity to achieve and maintain an acceptable level of learning. Every child has unique characteristics, interests, abilities and learning needs. Education systems should be designed and educational programs implemented to take into account the wide 
diversity of these characteristics and needs, and those with special educational needs must have access to regular schools which should accommodate them within a child-centered pedagogy capable of meeting these needs. This means that, apart from education being the fundamental right of a child, it must also take into account an acceptable level of learning.

An acceptable level of learning considers the characteristics, interests, abilities and learning needs of the child. What the system must therefore seek to do is to equip the individual with the necessary skill and abilities to help solve the socio-economic problems of society. These all build up to the quality of infrastructure in the sector of education. Since reading and instructional materials, science laboratories and good learning environments enhance the delivery of quality education, the government of Ghana has for over the years enacted and implemented several legislations, policies and initiatives to ensure that teaching and learning standards are improved.

The establishment of the GET fund for example, was to help reduce the weight of educational problems on government. The GET fund was to support staff and infrastructural development in tertiary institutions as well as secondary and primary schools. The fund also provides scholarships for brilliant but needy students. The fund however, is highly over stretched by the quantum of problems it seeks to solve to provide quality education to Ghanaians. Also, results obtained by students from WAEC/WASSCE and the spoken languages of the students in the public domain today are indicative factors of low quality education.

The questions asked are whether there are enough instructional materials (well-resourced laboratories, modern libraries among others) in second cycle schools, quality teachers and support from the private sector. It is against this backdrop that an assessment of the role of private schools in providing quality secondary education is imperative for providing quality education in Ghana.

\section{Historical Perspective}

The colonial government's attempt to provide formal education in the colony came in the mid-1850s. More than two hundred years after its introduction into the country. Generally speaking, the development of private education in Ghana can be classified into two main streams; namely, the castle schools, which were the antecedents of the present day one-man proprietary schools, and the mission schools.

The establishment of castle schools was considered as the earliest attempt at introducing formal education in Ghana. The first of these schools was the one established by the Portuguese at the Elmina Castle in the late sixteenth century. Formal education began around 1752 when one of the early missionaries of the Society of the Propagation of the Gospel (SPG), Rev. Thomas Thompson, arrived and established a school in Cape Coast (Graham, 1976). Unfortunately, the school closed down when Thompson left the Gold Coast probably due to illhealth. Philip Quaque then started a private school and re-opens the castle schools (Graham, 1976). He however faced the challenge of co-operation of the castle authorities as well as being ostracized by his own people.

Another factor that sustained Quaque's endeavor was the support he had from the Torridzonian Society founded in 1787. By 1792, however, their efforts collapsed due to lack of commitment and interest. In 1829, the colonial school was established and Joseph Smith of Cape Coast was appointed the headmaster. He received support from the then governor, Captain George Maclean, for the establishment of the school as an educational force. It is worth noting that different merchant companies with distinct national backgrounds established the castle schools. Their common aim was to Christianize the Africans as well as to train personnel, specifically clerks and interpreters for their commercial activities. Their curricula and educational models varied according to those of their different countries.

Moreover, the missionaries were the second group of people to provide formal education in the country. Their arrival into the scene brought with it vigor and an apostolic zeal. It must be noted however, that the purpose and methods of education of the various missions varied accordingly. Just like the castle schools, the mission schools reflected the models of the educational systems from which the various missions came as well as the missions and philosophies of these Christian bodies. For instance, according to Quist (2003), the first Methodist Church Secondary School, Mfantsipim School was modeled on English Wesleyan Schools. Notable among these missions included the Wesleyans, Basel, Bremen, German and Catholic. Each mission made efforts to broaden the scope of their curriculum and train teachers for their schools. For instance, the Basel mission established the first teacher training college at Akropong-Akuapem.

Conversely, a conscious attempt was also made by each of the missions to procure relevant teaching and learning resources for their schools. In fact, not only were the missions regarded as the right bodies to manage education; they had more money than the government to do so (Eyiah, 2004). The Colonial government took an active part in the provision and management of education only after 1880 (Graham, 1976). The initial attempt by the government to participate in the provision of education was in the form of the introduction of various education ordinances first to guide the operations of the already existing private schools and later to guide the organization of its own schools. The first was the Education Ordinance of 1852, which provided that the Gold Coast schools were to be financed by an annual sum of $£ 1,000$, which was mainly to be derived from the proceeds from the Poll Tax. It also provided for a Board of School Visitors and in 1856, Rev. C. S. Hassels was appointed superintendent 
and inspector of schools and was charged to oversee the requisite supply of teachers of good quality by his own training (McWilliams\& Kwamena-Poh, 1975).

Whereas the government's efforts in the provision of schools declined, the missions progressed steadily in their endeavors. Therefore, after 1874, the government decided to primarily focus on using its money spent on education to help the missions in their efforts in the form of grants. Two different types of schools therefore came under this system; government schools and assisted schools. Consequently, the 1882 Education Ordinance established a Board of Education to control and supervise the system. The principal of Fourah Bay College in Sierra Leone, Rev. M. Sunter, was appointed Inspector of Schools who was to report to the board as to whether those managing the assisted schools observed the conditions on which the grants were given.

To solve the problems this system posed in 1890, a Director of Education was appointed for the Gold Coast alone. The introduction of the Accelerated Development Plan for Education in 1951 brought with it a rapid expansion of primary education. The result of the massive infrastructural development in this period was that, over 132,000 children began their primary school in 1952 and more than twice the previous year. By 1957, there were over 450,000 children in the primary schools and they were taught by about 15,000 teachers (McWilliams\& Kwamena-Poh, 1975). In order to ensure equal access to education for all Ghanaian children, attempts were also made by the government to monopolize the management of education. Consequently, missions were asked to hand over their schools to the Local Authorities. No mission or private individual was to open a new school except otherwise permitted by the Local Authorities. However, missions were later allowed to manage the already existing denominational schools. The scheme also provided for a District Education Officer and Assistant Education Officers were also appointed each of whom was to give advice and guidance to about thirty primary schools.

Following independence, a Ministry of Education was set up and was headed by a minister. Local Authorities were to continue providing infrastructure for teaching and learning. Under the Education Act of 1961, the Ministry of Education was empowered to establish Local Education Authorities to (a) build, equip and maintain all public primary and middle schools in its area; (b) establish all such primary, middle and special schools as are in the opinion of the Minister; and (c) advise the Minister on all matters relating to primary and middle school education in its area (McWilliams\& Kwamena-Poh, 1975). Every local authority was to work through an education committee of nine members, at least two of which were to be nominated by the Educational Units, which were the management bodies of the mission schools. It is also important to note that, while the central government would pay for teachers where there were schools, the existence of the schools depended completely on the Local Education Authority.

Thus, towards the end of colonial rule through to the independence era, government's policies on education gave little attention to private schools and where it did the attempt was not to favor their progress as partners in the provision of education. This trend started changing from the 1950s. For instance, between 1951 and 1957 and between 1957 and 1966, there was almost 300\% increase in the number of public secondary schools. Likewise, enrolment in public secondary schools rose by approximately $300 \%$ the same periods (Quist, 2003). Such increases however, did not affect the private school 1evel where a decline of $200 \%$ in the total number of schools between 1951 and 1957 can be discerned. This implies that public secondary education expanded steadily at the expense of the private sector and this was as a result of the then government's "policy of using the private sector to augment the public domain" (Quist, 2003,).

Private education must fill the inevitable gaps in public education. A lack of firm political support sometimes can limit the degree to which governments can assist public schools to develop (see James and Birdsall, 1991; Birdsall and James, 1993). Even when they are politically motivated to do so, as in many developing countries, governments are often under such severe financial constraints that they cannot afford to finance even a high return activity such as education (World Bank, 1986). The result is an excess demand for public enrollment. James characterizes two other motivations for the establishment of private schools: a differentiated demand arising from a deep-seated religious or linguistic diversity and an offer on the part of an entrepreneur or organization, often religious, to start the schools on a nonprofit basis. She hypothesizes that, in many developing countries, it is excess demand that prompts the development of private education, whereas it is differentiated demand that has the same effect in developed countries. This situation may change as countries develop and differentiated demand becomes a bigger motivator of private education (James, 1988, 1989a, 1986b, 1986).

The second role that private education can play is in fostering greater efficiency by requiring public schools to compete for students. Although there are many types of private schools, analysts have argued that they possess general characteristics that differentiate them from public schools. These characteristics include a greater flexibility in operation and in funding, a direct accountability to those who use their services and a greater tendency for those in charge of individual schools to make critical educational decisions (Coleman, Hoffer and Kilgore, 1982). It is often argued that these characteristics enable private schools to provide education more effectively. In other words, to provide the type and quality of education students and their parents demand. Moreover, even when the quality of education is similar, private schools have the incentive to operate at a lower cost than their public school counterparts. 
Third, private schools can serve as a laboratory for alternative models of school-level management which, if effective, could be adopted by public schools. Theoretically, private schools are free of the bureaucratic constraints that encumber public schools and are able to control many more decisions at the school level. It is argued that, if public schools were given the degree of school-level autonomy that private schools enjoy, this would boost achievement levels in public schools. Not all analysts agree that public schools would be able to emulate private schools, because of the differences in their sources of support. They reason that, private schools emphasize learning because parental funding makes private schools accountable to parents' demands for effective instruction. By comparison, public schools pay less attention to learning because, they need to balance professional accountability to parents with fiscal accountability to the centralized funding source.

If correct, these theories have substantial policy implications for developing countries. At present, private schools play only a peripheral role as a conduit for educational expansion. Can this be changed? Should private schools be deregulated? Should they be subsidized? Some analysts have argued that these schools are only for the elite. Others have said that private schools should not be encouraged because, they will provide low-quality education at high cost to gullible parents and students. Like all good theories, these arguments lead to the following testable hypotheses: The private schools are relatively more effective and efficient than the public schools. This is due to the differences in school-level management.

In education, quality continues growing as an interesting area of research. Studies have further been conducted on different perspectives trying to define the quality in education (Parri, 2006 \& Manyanga, 2007). In Lomas (2002), quality in higher education is described using four perspectives; fitness for purpose, value for money, transformation and excellence. Parri (2006) used six perspectives: exceptional or excellence, zero error, fitness for purpose, transformation or reshaping, threshold and enhancement. For purpose, value for money, transformation and excellence perspectives define quality education clearly and relevantly. Relevance is taken from the fact that, education aims to offer knowledge, skills, and capabilities according to the requirements of society (Lomas, 2002). In addition, education is taken as a developmental process where students are academically raw at entry and are transformed to acquire knowledge, skills and competences (Hakielimu, 2007). More importantly, schools and students strive to achieve high standards in their performances so as to exceed others (Mosha, 2000). From this line of thinking, the quality of education can generally be discussed from these perspectives. From its developmental process, education needs improvements from time to time, thus the adoption of enhancement and empowerment are important to explain the developmental process (Parri, 2006). From this adoption, quality of education can further be defined as the qualitative change characterized by excellence in performance towards achieving end results. The end results in this case are knowledge, skills and capabilities, while performance is referred to the teaching and learning process.

Education results derive from the interaction of students (with their families), teachers, and schools; outcomes will also be affected by student peers. Furthermore, the institutional set up, e.g. decentralization schemes, competition, charter schools, accountability systems and the like, have impact on the final education quality outcome. Research has found that education quality is a key factor to economic growth (Hanushek and Kimko, 2000 ) and that, private returns of education quality are high and maybe higher in developing countries- (Hanushek and Zhang, 2006). Furthermore, education quality has impact on health related issues (Hanushek, Jamison and Jamison, forthcoming), and that education quality may be a key determinant of school dropout. (Hanushek, Lavy, Hitomi, 2006).

Private schools are schools, which are not administered by local, state, or national government, which retain the right to select their student body and are funded in whole or in part by charging their students' tuition rather than public (state) funds (UNESCO, 2000). In the Ghanaian context, private school refers to any educational institution established and operated by persons or groups of persons other than the central or local governments. Private education in Ghana covers the whole gamut of educational activity ranging from pre-school to tertiary level institutions. Doubtless to say that secondary education is the backbone for economic growth and employment (DfID, 2006). The contribution of secondary education, both public and private to the socio-economic development of Ghana, is phenomenal. This underscores Quist (2003) assertion that, secondary education as provided in Ghana remains crucial to the country's economic growth and national development, sustained literacy as well as the cultivation of a sense of national unity.

The recognition of the invaluable role of secondary education to the forward march of the nation development has motivated private individuals and agencies to provide this level of education to the teaming youth in the country. These education conscious individuals regard it imperative for an increased access to secondary education to meet the accelerated growth in the student population at the junior high level. The limited vacancies in the public senior high schools cannot absorb all the qualified JHS graduates. In the 2009/2010 academic year, there were 178,000 vacancies for the 206,642 candidates who passed the 2009 BECE and qualified to enter senior high school in the country (Appiah, 2009).

Apparently, all those candidates who cannot get places in the public schools as well as those who were denied access in the previous years due to limited vacancies but are desirous of furthering their education would have no 
option than to look for vacancies in the private sector. Thus, the private sector helps to expand access of education to those who fail to gain admission into the existing public secondary schools. Private senior high schools broaden the range of secondary education experience and provide access to those who wield the intellectual energy and capacity but do not get the chance to be in the public ones. They provide opportunity for the youth to benefit from high education and consequently higher education.

Furthermore, the private sector's role in developing the human capital for accelerated development of countries is indisputable. Private secondary schools complement the effort of the public sector to develop the skills, knowledge, competencies and talents of the youth. They assist to create equal platform to unearth the potential and capabilities of many junior high school graduates to enable them contribute meaningfully to the development of the nation. This invariably helps to create an elite society, contribute to the development of the society and reduce income inequality.

\section{Methodology}

The study adopted the quantitative and qualitative approaches. The sampling method applied was the purposive and simple random. The purposive sampling technique was used to collect data from 20 management staff of GES while the simple random sampling was used for collecting data from 150 people comprising heads, teachers and parents across the senior high schools and districts in the Upper East Region. The study implemented the data based on triangulation procedure by means of a mixture of data sources with the consequence that, the strengths and weaknesses in each source are compensated when used together. Primary and secondary data were both selected for the study. The Primary data was qualitative and obtained from selected key informants who play very influential role in education in the Upper East Region. District Chief Executives, Regional Director of Education, headmasters, teachers and other key players in education were selected for interview. In adding up to interviews as the foremost mechanism, these methods were supplemented with informal observation. Secondary data included statistics of students' performances in the West African Senior Secondary School Certificate Examinations (WASSCE), and other descriptive data; such as staff student population, available facilities etcetera. The secondary data was taken from selected private and public senior secondary schools and the data was quantitative.

Interviews and questionnaires were used to collect data. The interview questions were inspected for its general content, validity and attention to detail. Remarkable advice and comments were integrated in the final survey instrument. The instrument was checked to be certain that the questions were explicit and answerable before they were at last administered.

The data collected was examined for consistency of responses. All continuous variables were coded directly becoming nominal variables; percentages and frequency tables were compiled using statistical software known as statistical package for social science (SPSS). Tables were constructed to merge responses for those who answered "very true (vt)" and "(t)" to denote "true" and "very untrue (vu)" and "untrue (u)". The ratings on the Likert scale were therefore reduced to only two dimensions namely "true (t)" and "untrue (ut)". In fact, this was done to show whether respondent's opinion is true or untrue to a particular item.

\section{Analysis and discussion}

\subsection{Determinants of Quality Education}

Quality education is contingent upon the identification of quality determinants. It goes without saying that; quality education cannot be obtained without first identifying its determinants. The study sought to ascertain the determinants of quality education.

Table 1: Determinants of quality education

\section{Determinants}

Prevalence of well experience teachers

Availability of Instructional Materials

Presence of motivated Teachers

Effective monitory and supervision

Strict adherence to individual differences in instructional delivery

Effective time management

Identification of problem student

Strict adherence to student teacher ration Attractive and conducive school environment Organizing extra class

Rise in success rate of students in final examination

Key: VT-very true, $T$-true, $U S$-unsure $\quad U T$-untrue, $V U$-very and $U$-untrue

From the study as presented in table 1, out of the total number of 150 respondents, the presence of well

$\begin{array}{cccccccccc}\text { VT } & \% & \text { T } & \% & \text { US } & \% & \text { UT } & \% & \text { VU } & \% \\ 96 & 64 & 35 & 23.3 & 1 & 0.7 & 12 & 8 & 6 & 4 \\ 92 & 61.3 & 43 & 28.7 & 3 & 2 & 7 & 4.7 & 5 & 3.3 \\ 86 & 57.3 & 36 & 24 & 2 & 2.7 & 16 & 10.7 & 8 & 5.3 \\ 79 & 52.7 & 39 & 26 & 3 & 2 & 19 & 12.6 & 10 & 6.7 \\ 70 & 46.7 & 48 & 32 & 5 & 3.3 & 20 & 13.3 & 7 & 4.7 \\ & & & & & & & & & \\ 69 & 46 & 53 & 35.3 & 1 & 0.7 & 24 & 16 & 3 & 2 \\ 61 & 40.7 & 48 & 32 & 8 & 5.3 & 19 & 12.7 & 14 & 9.3 \\ 53 & 35.3 & 58 & 38.7 & 9 & 6 & 18 & 12 & 12 & 8.0 \\ 60 & 40 & 51 & 34 & 6 & 4 & 25 & 16.7 & 8 & 5.3 \\ 57 & 38 & 58 & 38.7 & 7 & 4.6 & 24 & 16 & 5 & 3.3 \\ 86 & 57.3 & 36 & 24 & 2 & 2.7 & 16 & 10.7 & 8 & 5.3\end{array}$


experienced teachers determines quality education registered $64 \%$ and $23.3 \%$ very true and true respectively $(87.3 \%$ cumulatively), $0.7 \%$ were unsure while $8 \%$ and $4 \%$ untrue registered untrue and very untrue (12\% cumulatively. Availability of teaching and learning materials determines quality education registered $61.3 \%$ and $28.7 \%$ very true and true respectively (90\% cumulatively), $2 \%$ were unsure while $4.7 \%$ and $3.3 \%$ registered untrue and very untrue respectively ( $8 \%$ cumulatively). The presence of motivated teachers) and rise in success rate of student in final examination registered $57.3 \%$ and $24 \%$ very true and true respectively (82.7\% cumulatively). Also, effective monitoring and supervision registered $52.7 \%$ and $26 \%$ very true and true (78.7\% cumulatively) $2 \%$ were unsure while $12.6 \%$ and $6.7 \%$ registered untrue and very untrue $(19.3 \%$ cumulatively). Strict adherence to individual differences in instructional delivery registered $46.7 \%$ and $32 \%$ very true and true $(78.7 \%$ cumulatively) $3.3 \%$ were unsure while 13.3 and $4.7 \%$ registered untrue and very untrue (18\% cumulatively). Effective time management registered $46 \%$ and $35.3 \%$ very true and true ( $81.3 \%$ cumulatively), $0.7 \%$ were unsure while $16 \%$ and $2 \%$ registered untrue and very untrue (18\% cumulatively). Identification of problem children registered $40.7 \%$ and $32 \%$ very true and true $(72.7 \%$ cumulatively), $5.3 \%$ were unsure while $12.7 \%$ and $9.3 \%$ registered untrue and very untrue ( $22 \%$ cumulatively). Further, strict adherence to student-teacher ratio registered $35.3 \%$ and $38.7 \%$ very true and true (74\% cumulatively), $6 \%$ were unsure while $12 \%$ and $18 \%$ registered untrue and very untrue $(20 \%$ cumulatively). Attractive and conducive school environment registered $40 \%$ and $34 \%$ very true and true $(74 \%$ cumulatively), $4 \%$ were unsure while $16.7 \%$ and $5.3 \%$ registered untrue and very untrue (22\% cumulatively). Finally, organizing extra-class registered $38 \%$ and $38.7 \%$ very true and true $(76.7 \%$ cumulatively), $4.6 \%$ were unsure while $16 \%$ and $3.3 \%$ registered untrue and very untrue (19.3\% cumulatively).

From the analysis above, it is realized that, the greater majority of the respondents consider availability of teaching and learning materials (90\%), effective monitoring and evaluation(89.3\%), presence of well experienced teachers $(87.3 \%)$, effective time management, presence of motivated teachers and rise in success rate of students in final examinations $(81.3 \%$ respectively), strict adherence to individual differences in instructional delivery $(78.7 \%)$, organizing extra-classes $(76.7 \%)$, attractive and conducive school and strict adherence to studentteacher ratio $(74 \%$ respectively $)$ and identification of problem students $(72.7 \% \%)$ are critical determinants of quality education.

It is worth stating that the critical determinants of quality education are availability of teaching learning materials, effective monitoring and evaluation, experienced and motivated teachers, effective time management and success in examinations, adherence to individual differences, extra- class, appropriate student-teacher ratio and conducive school environment and identification of problem students. Thus, tremendous efforts should be made by GES to strengthen or reinforce these determinants. To succeed in raising academic achievement, the provision of education is mainly center on the teaching force (Sumra and Rajani, 2006). Research shows that, teaching is the strongest determinant of the quality of education (UNESCO, 2004; Dembélé and Lefoka, 2007).

\subsection{Respondents' ratings on the standards of education in the Upper East Region of Ghana}

The respondents were asked of their ratings on the standards of education in the Upper East Region. This question was meant to discover the degree of quality of education in the region. A number of responses were given.

\subsubsection{Reasons for Low Quality of Education}

The fact that a solution to a problem cannot be found without first identifying the cause of it is a universally accepted phenomenon. The research sought to determine the reasons responsible for the low quality of education in the Upper East Region.

Table 2: Reasons for Low Quality of Education

\section{REASON}

Insufficient teachers

Teachers absenteeism

Lack of supervision

Infrastructural deficit

Unavailable facilities

Frequent transfers of teachers

Lateness on the part of heads and teachers

Lack of textbooks

$\begin{array}{clll}\text { Yes } & \% & \text { NO } & \% \\ 136 & 90.7 & 14 & 9.3 \\ 126 & 84 & 24 & 16 \\ 96 & 64 & 54 & 36 \\ 139 & 92.7 & 11 & 7.3 \\ 120 & 80 & 30 & 20 \\ 69 & 46 & 81 & 54 \\ 81 & 54 & 69 & 46 \\ 123 & 82 & 27 & 18\end{array}$

As indicated in table 2 , out of the total number of 150 respondents, as much as $90.7 \%$ asserted that the low quality education was attributed to insufficient teachers while $9.3 \%$ thought it was not attributable to insufficient teachers. Eighty-four percent (84\%) thought teacher absenteeism was responsible for the low quality of education while $16 \%$ said no to that assertion. Sixty-four percent (64\%) blamed the low quality on lack of supervision as being the cause of low quality of education. Also, as much as $92.7 \%$ thought infrastructural deficit was the cause of low quality education while $7.3 \%$ said no to that. Eighty $(80 \%)$ reiterated that, unavailability of learning facilities is responsible for low quality of education while $20 \%$ saw unavailability of learning facilities not to be responsible for the situation. Further, $46 \%$ were of the opinion that frequent transfers of heads and teachers were 
the causes of low quality education while $54 \%$ did not think transfers could cause low quality education. Fiftyfour percent (54\%) saw lateness of heads and teachers to be the reason for low quality education. Finally, $82 \%$ were optimistic that lack of textbooks accounts for low quality while $18 \%$ saw lack of textbooks as not being a reason for the low quality of education.

It is crystal clear from the above analyses that diversity of reasons exists for the low quality of education in the Upper East Region. These reasons include infrastructural deficit (92.7\%), insufficient teachers (90.7\%), teacher absenteeism (84\%), lack of textbooks $(82 \%)$, unavailability of facilities and lateness $(54 \%)$. It is surprising however that frequent transfers do not contribute greatly to low quality of education. Thus, it is possible to generalize that the Upper East Region is bedeviled with a number of problems leading to low quality of education. The Ministry of Education should endeavor in reinforcing the identified problem areas. This analysis is coterminous with (Bedi and Sharma, 2006) assertion that proposals to improve the quality of education are based on the assumptions that schools are failing to meet the requirements of society and hence transformation is needed.

\subsubsection{Contribution of Private Schools in Ensuring Quality Education}

In ascertaining the contributions made by private schools in ensuring quality education; the respondents were asked of the contributions of private schools.

\section{Table 3: Contribution of Private Schools in Ensuring Quality Education}

\section{Contribution}

evaluation

Careful attention to each individual student

In class casting the habit of leaning in student

Provision of educational infrastructure

Augmenting the public schools in their effort to provide quality education

High performance of students in final exams

$\begin{array}{cccccccccc}88 & 58.7 & 44 & 29.3 & 3 & 2 & 12 & 8 & 3 & 2 \\ 70 & 46.7 & 51 & 34 & 3 & 2 & 18 & 12 & 8 & 5.3 \\ 101 & 67.3 & 23 & 15.3 & 4 & 2.7 & 21 & 14 & 1 & 0.7 \\ 131 & 87.3 & 6 & 4 & 1 & 0.7 & 8 & 5.3 & 4 & 2.7 \\ 71 & 47.3 & 38 & 25.3 & 6 & 4 & 21 & 14 & 14 & 9.3\end{array}$
$29.3 \%$ (88\% cumulatively), $2 \%$ were unsure while untrue and very untrue recorded $8 \%$ and $2 \%$ cumulatively). For careful attention, very true and true recorded $46.7 \% 34 \%(80.7 \%$ cumulatively), $2 \%$ were unsure while untrue and very untrue recorded $12 \%$ and $5.3 \%$ (17.3\% cumulatively). For inculcating in their students, the spirit of learning, very true and true recorded $67.3 \%$ and $15.3 \%$ ( $82.6 \%$ cumulatively), $2.7 \%$ were unsure, while untrue and very untrue recorded $14 \%$ and $0.7 \%$ (14.7\% cumulatively. Also, for provision of educational infrastructure and high performance of students in final examination respectively, very true and true recorded $87.3 \%$ and $4 \%(91.3 \%$ cumulatively), $0.7 \% \%$ were unsure while untrue and very untrue recorded $5.3 \%$ and $2.7 \%$ ( $8 \%$ cumulatively). Finally, for augmenting the public schools, very true and two recorded $47.3 \%$ and $25.3 \%$ (72.6\% cumulatively), $4 \%$ were unsure while untrue and very untrue recorded $14 \%$ and $9.3 \%(23.3 \%$ cumulatively).

From the analysis, it is evidently clear that, provision of educational infrastructure and high performance of students in final examinations $(91.3 \%)$, monitoring, supervision and evaluation of teachers $(88 \%)$, inculcating the spirit of learning $(82.6 \%)$, careful attention given to students $(80.7 \%)$ and augmenting the public schools are the areas of contribution of private schools to quality education. It can therefore be generalized that, the contribution of private schools to quality education is enormous and there is an urgent need for the Ministry of education to team up (enter into partnership) with the private education sector to provide quality education in the country.

\subsubsection{Challenges private schools face in providing quality education}

When the respondents were asked of the challenges faced by private schools in ensuring quality education, they gave varied responses. Majority of respondents mentioned funding for infrastructure, inadequate professional teachers, untimely payment of school fees, excessive expectations of parents towards their wards' performance, minor interference by parents in administrative issues among others. On the part of inadequate professional teachers, Alani (2000) asserted that lack of qualified teachers caused high failure rate in the secondary school certificate examination.

\subsubsection{Public-Private Partnership in Ghana}

In an attempt to ascertain whether a public-private partnership exists for quality education, the respondents were asked whether there is a public-private partnership in place to work toward improving quality education in the second cycle educational sector. The majority said they were not too sure but what they know is decisions made by Conference of Heads of Assisted Secondary Schools (CHASS) during meetings are binding on both the public and private schools. This means that a clear partnership between the public and private educational sector does not exist to promote quality education. Perhaps, what needs to be done is to develop public - private partnership, which is capable of comprehensively dealing with educational issues. "In Africa, a region in which the challenge to fulfill the Millennium Development Goals (MDGs) is dire, a dynamic private sector has expanded the access to quality of education through a variety of public-private partnerships. The new private providers are aiming to offer 
a more conducive learning environment than the public schools provide (World Bank, 2009).

\subsubsection{Suggestions of Respondents}

When the respondents were asked to suggest ways of providing quality education, a number of recommendations were given. The majority of them recommended that private schools in the second cycle should be allowed access to the Ghana Education Trust Fund (GET fund), that they should be an effective public-private partnership and that N.G.Os should be actively involved in the provision of quality education. Also, they recommended that Ghana Education Service (GES) and the Ministry of Education should put an effective monitoring and evaluation system in place. The respondents further recommended active involvement of strategic stakeholders in the management and administration of schools. They finally recommended that, a quota of the posting of professional teachers to second cycle schools should be given to the private schools by way of government's contribution to private schools.

\section{Management Assessment of Quality Education}

\subsection{Institutional assessment}

On the institutional assessment, the management of the GES were given an interview schedule covering areas such as meaning of quality education, indicators of quality secondary education, reasons for falling standards in second cycle education, whether there is infrastructural deficits in schools, teacher deficits in schools, effects of teachers' deficit, efforts made to solve problem of teacher deficit, assessment of teachers in institutions, the effects of government subvention to quality education.

On the meaning of quality education, the majority of the respondents defined it as, a comprehensive education. Thus quality education is one that provides all learners with capabilities they require to become economically productive, develop sustainable livelihoods, contribute to peaceful and democratic societies and enhance individual well-being.

For the indicators of quality education, they mentioned experienced teachers, availability of learning facilities, individual differences, teacher commitment, and effective supervision among others. On the issue of falling standards in the Upper East Region, majority of management mentioned inadequate professional teachers, logistical problems, and refusal of teachers to go to rural areas, teacher absenteeism among others. All the respondents agreed that, there is infrastructural deficit and advanced reasons such as delays by contractors to complete projects and lack of funds on the part of government. They also agreed that there was deficit in the attainment of quality education and that efforts are being made to remedy the situation and this was in the form of bringing in more professional teachers and employing very few non-professional teachers who are often sent to rural areas. On the issue of the effects of teacher deficit, the majority of them said it leads to low quality of education. They also reiterated that, teacher deficit is caused by few numbers of professional teachers posted to the region and frequent transfers of teachers. Also, on the issue of the efforts made to solve teacher deficit, the majority of the respondents said some non-professional and pupil teachers are employed to augment the professional teachers in the region.

Finally, on the assessment of teachers in institutions, the majority of management stated categorically that, many of the teachers were committed and focused but a few of their performances leave much to be desired.

\subsection{Role of Private Sector in Providing Quality Education}

When asked of the role played by private schools in quality education, the majority mentioned provision of infrastructure, effective extra classes, inculcating the spirit of learning in students, effective monitoring of students, careful attention to students, modifying the behavior of students among others. The respondents also agreed that government subvention enables them to provide infrastructure and learning facilities.

\subsection{Suggestions by Management of GES}

When management was asked to suggest ways of ensuring quality education in the second cycle education, they gave responses similar to those suggested by the heads, teachers and parents.

\section{Table 4: Suggestions by management of GES}

Suggestions

Public - Private Partnership

Involvement of NGO's

Monitoring \& Evaluation

Involvement of Strategies Stakeholders

Relocation of Non-Performing teachers

Total

As indicated in table 4 , the majority of them mentioned public-private partnership (25\%), involvement of $\operatorname{NGO}(25 \%)$ as well as monitoring and evaluation (25\%); few of the respondents however, mentioned involvement of stakeholders $(15 \%)$ and relocation of non-performing teachers to JHS and primary schools $(10 \%)$. From the analysis above, it is seen that a lot of things contribute to quality education. It is important to deal with those factors 
first. In fact, the issue of quality education needs to be tackled comprehensively and incrementally. This is because, it is not possible to effect quality education in quantum or at once. The issues need to be handled one after the other.

\section{Conclusion}

The study reveals that heads and teachers of second cycle institutions are qualified with attractive remunerations. Quality education dependent on identification of problem students, availability of teaching and learning materials, effective time management, well experienced teachers, presence of motivated teachers and rise in success rate of students in final examinations, effective monitoring and supervision and strict adherence to individual differences in instruction delivery. Private educational institutions contribute tremendously towards quality education. Their roles are in the areas of provision of infrastructure and high performance of students in final examination, monitoring and evaluation, inculcating in students the spirit of learning, careful attention to students and augmenting the public sector in quality education delivery. Low quality of education is attributable to infrastructural deficit, inadequate teachers, teacher absenteeism, and lack of textbooks, unavailable facilities and lateness. A strong partnership between the public and private sector is invaluable in ensuring quality education. Private schools are constraint with funding for infrastructure, inadequate professional teachers, untimely payment of school fees by parents, excessive expectations from schools by parents, excessive expectations of parents towards their wards' performance and interference by parents in administrative issues. A critical strategy for addressing quality education issues in the private schools is to allow them access to the GETfund. There should be public-private partnership for quality education, effective monitoring and evaluation systems, involvement of strategic stakeholders etc. Finally, quality education in the second cycle education needs to be tackled comprehensively and incrementally.

The study concludes that the heads and teachers of second cycle education are qualified, experienced and receive quite an attractive remuneration. Quality education for the second cycle education is contingent on identification of problem students, availability of instructional materials, etc. The private educational sector's contribution to the provision of quality education is enormous. There is an urgent need for public-private partnership in the provision of quality education. Low quality of education is attributable to a number of factors including infrastructural deficit, inadequate teachers, teacher absenteeism, etc. The private educational institutions in second cycle education are faced with serious challenges which militate against quality education. Private schools should have access to GETfund, etc. Quality education issues should be tackled comprehensively and incrementally.

The study recommends a dynamic public- private partnership to ensure quality education; the private educational sector should be allowed access to the GETfund for provision of educational infrastructure and other educational facilities and logistics and effective monitoring and evaluation system in the educational sector which should be implemented to the letter. Also, non-governmental organizations and other strategic stakeholders' participation and involvement should be invigorated in the efforts to deliver quality education. Their views should be solicited in any major educational policies and implementation of major changes. Quality education in the second cycle education should be dealt with comprehensively and incrementally. A comprehensive change program or reengineering is required to ensure quality education. Educational authorities should establish some form of collaboration with Ghana Youth Employment and Entrepreneurial Agency for regular supply of nonprofessional graduate teachers to the second cycle institutions (both public and private).

\section{Acknowledgement}

The support in the form of research facilities and the cooperation of management staff of GES and heads, teachers and parents across the senior high schools in the Upper East Region who provided responses to the research survey, as well as all references made in journals are gratefully acknowledged.

\section{References}

Alani, R. A. (2000). Secondary education in transition in Nigeria: The question of quality. Journal of Educational management, 1(3), 99-109.

Appiah, K.P. (2009) GETfund supports Amarhia JHS. Daily Graphic. (No.18016) pp. 11

Bedi, K. and Sharma, J. K. (2006). Benchmarking the quality of secondary education at the micro and policy imperatives. U21 Global working paper

Birdsall, N. and James. E. (1993). Efficiency and equity in social spending: How and why governments misbehave. In J. van der Gaag (Ed.), Including the Poor. (pp.335-59) Washington, D.C.: World Bank

Coleman, J., Hoffer, T. and Kilgore, S. (1982). High school achievementpublic, Catholic and private schools compared. New York: Basic Books.

Dembélé, M. and Lefoka, P. (2007). Pedagogical renewal for quality universal primary education: Overview of trends in Sub-Saharan Africa. International review of education, 53, 531-553. 
Eyiah, K.J. (2004). Which way with Secondary Education. A Guide for Educational Administration. Accra: Ghana Education Service.

Graham, C. K. (1976). The History of Ghana, Accra: Ghana Publishing Corporation.

Hanushek, E.A and J. Luque (2000). Smaller Classes, Lower Salaries? The Effects of Class Size on Teacher Labor Markets, in Sabrina W.M. Laine and James G. Ward (ed.), Using What We Know: A Review of the Research on Implementing Class-Size Reduction Initiatives for State and Local Policymakers (Oak Brook, Ill.: North Central Regional Educational Laboratory, 2000), pp. 35-51

Hanushek, E.A. and J.Luque (2003). "Efficiency and equity in schools around the world." Economics of Education Review 22, no 5 (August): 481-502

James, E. (1986).Differences in the role of the private educational sector in modern and developing countries. Unpublished manuscript, State University of New York, Stony Brook.

James, E. (1988). Benefits and Costs of Privatized Public Services: Lessons from the Dutch Educational Svstem. In Geoffrey Walford (Ed.), Private Schools in Ten Countries: Policy and Practice (pp. 179-200). L.ondon: Routledge and Kegan Paul

James, E. (1989). Public and Private Education in International Perspective. In W.L. Boyd and J. Cibulka (Eds.), Private Schools and Public Policy: International Perspectives (213-236). London: Falmer Press.

James, E. (1991). Public policies toward private education. International Journal of Educational Research, 15, 359$376 \ldots$

Lomas, L. (2002). Does the Development of Mass Education Necessary Mean the end of Quality? Quality in Higher Education, 8, (1), 71 - 79.

Lomas, L. (2007). Zen, Motorcycle maintenance and quality in higher Education. Quality assurance in education, Vol. 15(4), 402-412.

Manyanga, T. (2007). Standards for quality in tertiary education: The case of Tanzania. Quality assurance in education, Vol. 16(2), 164-180.

Mcwilliam, H.O. A. \& Kwamena-Poh, M.A. (1975). The Development of Education in Ghana (1st ed.). London: Longman Co. Ltd.

Mosha, H. J. (2000). Conceptualizing quality education. In J.C.J. Galabawa, F.M.K. Senkoro and A.F. Lwaitama (eds) The quality of Education in Tanzania: Issues and experiences. Faculty of Education, University of Dar es Salaam.

Parri, J. (2006). Quality in higher education.Vadyba/management.m.Nr.2(11).

Patrinos, Harry Anthony, Felipe Barrera-Osorio, and Juliana Guáqueta. 2009 The role and impact of Public Private Partnerships in education. Washington DC: World Bank

Powell, A. G., Farrar, E. \& Cohen, D. (1985).The shopping mall high school.Bopston: Honghton-Miflin

Quist, H. O. (2003), 'Secondary Education in Ghana at the Dawn of The 20th Century. Profile, Problems, Prospects', Prospects, 29 (4), 425-42.

Sumra, S. and Rajani, R. (2006). Secondary education in Tanzania: Key policy Challenges. Working paper on The Norwegian Post- Primary Education Fund for East Africa (NPEF), Oslo, 13 - 14 Sept, 2006.

UNESCO (2004). Teacher's pay and conditions: An assessment of recent trend in Africa. EFA, Global monitoring report. Paris.

UNESCO. (2000), World education report. Paris: UNESCO.

World Bank (1986). Financing education in developing countries: An exploriation of policy options. Washington. D.C.: The World Bank.

World Bank (1990). World development report 1990. Poverty. Oxford University Press.

World Bank (1994). Better Health in Africa: Experience and Lesson- Development in Practice. Washington D. C.: World Bank.

World Bank. 2009. Patrinos, Harry Anthony, Felipe Barrera-Osorio, and Juliana

Guáqueta. The role and impact of Public Private Partnerships in education.http://siteresources.worldbank.org/EDUCATION/Resources/278200- 1099079877269/5476641099079934475/547667-1135281523948/2065243-1239111225278/Role_Impact_PPP_Education.pdf

Zhang, L. (2008). From conceptions of effective teachers to styles of teaching: Implication for higher education. Learning and individual differences, Vol. 19(1), 113 - 118. 